\title{
PENGARUH METODE ACTIVE DEBATE DALAM PEMBELAJARAN IPS TERHADAP HASIL BELAJAR AFEKTIF SISWA
}

\author{
THE EFFECTS OF THE ACTIVE DEBATE METHODS IN SOCIAL STUDIES LEARNING ON \\ AFFECTIVE LEARNING OUTCOMES
}

\author{
Happri Novriza Setya Dhewantoro, Taat Wulandari \\ Universitas Negeri Yogyakarta, Universitas Negeri Yogyakarta, \\ setya.dhewa@gmail.com, taat_wulandari@uny.ac.id
}

\begin{abstract}
Abstrak
Penelitian ini bertujuan untuk mengetahui pengaruh metode Active Debate dalam pembelajaran IPS terhadap hasil belajar afektif siswa di SMP Negeri 1 Jatisrono. Penelitian ini merupakan quasi experiment dengan pretest-posttest non-equivalent design. Populasi penelitian ini adalah seluruh siswa kelas VII SMP Negeri 1 Jatisrono. Sampel dalam penelitian ini diambil dengan teknik simple random sampling. Instrumen yang digunakan adalah angket. Data hasil belajar afektif dikumpulkan melalui angket. Validitas data menggunakan validitas isi dan valditas konstruk, reliabilitas data dianalisis menggunakan Alpha Cronbach. Data dianalisis menggunakan analisis regresi. Hasil penelitian menunjukkan ada pengaruh metode Active Debate dalam pembelajaran IPS terhadap hasil belajar afektif siswa. Peningkatan hasil belajar afektif siswa yang mendapatkan pembelajaran dengan metode Active Debate lebih tinggi dibandingkan peningkatan hasil belajar afektif siswa yang mendapatkan pembelajaran dengan metode ceramah. Hasil analisis regresi yang diperoleh dari kedua metode pembelajaran tersebut dapat dikatakan bahwa metode Active Debate sama-sama berpengaruh terhadap hasil belajar afektif siswa, artinya metode pembelajaran tersebut baik apabila diterapkan dalam pembelajaran
\end{abstract}

Kata kunci: active debate, hasil belajar afektif

\begin{abstract}
This study aims to know influence of Active Debate method in IPS learning toward student affective learning outcomes in SMP Negeri 1 Jatisrono. This was a quasi-experimental study using the randomized pretest-posttest control design pretest-posttest non-equivalent design. The research population comprised all students of Grade VII of SMP Negeri 1 Jatisrono. The sample was selected by means of the simple random sampling. The instruments were tests and questionnaires. The data on affective learning outcomes were collected through questionnaires. The validity was assessed in terms of the content and construct validity. The reliability was assessed by regression analysis. The results of the study were as follows there were effectts of Active Debate method in IPS learning to student affective learning result. Increased affective learning outcomes of students who get learning with Active Debate method is higher than the increase of affective learning outcomes of students who get learning by lecture method. Regression analysis test results obtained from both methods of learning can be said that Active Debate method equally affect the affective learning outcomes of students, meaning that the learning method were equally good to apply in learning.
\end{abstract}

Keywords: active debate, affective learning outcome 


\section{Pendahuluan}

Pendidikan diharapkan mampu melahirkan mampu melahirkan manusiamanusia yang berkompeten dan cerdas untuk menenetukan maju mundurnya suatu bangsa. Persaingan di masa mendatang menuntut pendidikan yang berkualitas tinggi. Mohamad (2015, p.1) menjelaskan bahwa daftar kualitas pendidikan yang dikeluarkan Organization for Economic Cooperation and Development (OECD), menempatkan Singapura sebagai negara yang memiliki kualitas pendidikan terbaik sedunia. Ada beberapa negara selain Singapura lain seperti Hongkong yang menempati urutan kedua, selanjutnya disusul oleh Korea Selatan. Ketika semakin banyak negara Asia menjulang di daftar buatan OECD ini, peringkat Indonesia hanya unggul tujuh peringkat dari Ghana yang ada di daftar terbawah.

Bersumber dari daftar kualitas pendidikan yang dikeluarkan oleh OECD tersebut, dapat dikatakan bahwa kualitas pendidikan di Indonesia masih rendah jika dibandingkan dengan negara-negara lain di dunia. Untuk mewujudkan pendidikan yang mampu melahirkan manusia-manusia yang berkompeten dan cerdas pendidikan yang, diperlukan perubahan dan perkembangan dalam pelaksanaan pendidikan di negara kita, diperlukan sumber daya manusia berkualitas tinggi yang mampu mengembangkan potensi yang dimilikinya serta dapat menyelesaikan permasalahan-permasalahan di masa mendatang.

Seiring dengan perkembangan

masyarakat dan kebutuhan yang semakin meningkat, upaya meningkatkan kualitas mutu pendidikan terus menerus dilakukan. Tidak heran hampir setiap hari manusia berusaha untuk merubah hidupnya untuk menjadi lebih baik melalui proses pembelajaran. Sanjaya (2011, p.21) menyatakan bahwa saat ilmu pengetahuan masih terbatas, saat penemuan hasil-hasil teknologi belum berkembang pesat seperti saat ini, peran utama guru di sekolah adalah menyampaikan ilmu pengetahuan sebagai warisan kebudayaan masa lalu yang dianggap berguna dan harus dilestarikan. Guru merupakan salah satu faktor yang penting dalam menentukan berhasil atau tidaknya proses pembelajaran.
Keberhasilan pendidikan sangat berkaitan dengan prosesnya, diperlukan pendidik dalam hal ini adalah guru yang profesional, handal, dan kompeten di bidangnya. Guru sebagai ujung tombak dalam pelaksanaan pendidikan merupakan pihak yang sangat berpengaruh dalam proses pembelajaran. Keterampilan guru dalam mengajar sangat menentukan kelangsungan pembelajaran di kelas. Guru yang memegang peranan penting dalam pembelajaran harus mampu menciptakan kegiatan belajar mengajar secara interaktif, inspiratif, menyenangkan, menantang, dan memotivasi siswa. Penting bagi setiap guru memahami proses pembelajaran agar mampu menciptakan pembelajaran yang kondusif.

Guru harus mampu mewujudkan langkah-langkah yang kreatif dan inovatif dalam proses pembelajaran, hal tersebut bermanfaat agar proses pembelajaran yang dialaksanakan tersebut bisa lebih bermakna. Gallagher, et al. (Charif, 2010, p.1) menyatakan "educational reform must take place in schools, new strategies are needed especially the ones that teach students to solve problems effectively". Pernyataan tersebut mempunyai arti guru diharapkan tidak saja mengajar dalam arti mentransfer pengetahuan kepada siswa, tetapi guru harus mampu mengispirasi siswa agar menggunakan struktur kognitifnya untuk berpikir, berpartisipasi, dan berinovasi dalam menyelesaikan permasalah yang dihadapi siswa dalam pembelajaran dan dalam kehidupannya sehari-hari.

Salah satu pembelajaran di Sekolah Menengah Pertama (SMP) adalah pembelajaran Ilmu Pengetahuan Sosial (IPS). Hasan (2013, p.6) mengatakan bahwa tujuan pendidikan IPS adalah untuk menghasilkan warga negara yang memiliki pengetahuan dan pemahaman tentang masyarakat dan bangsanya, religius, jujur, demokratis, kreatif, kritis, analitis, rasa ingin tahu, peduli dengan lingkungan sosial dan fisik. Pembelajaran IPS memberikan pembekalan pada siswa dengan menekankan pada ketrampilan siswa dalam memecahkan masalah. Pemecahan masalah tersebut dari lingkup diri sampai pada masalah yang kompleks, tidak hanya materi yang banyak dan menghafal saja, tetapi siswa diberi pembelajaran untuk bekal di kehidupan bermasyarakat. 
Zamroni (2007, p.280) mengungkapkan bahwa pengajaran ilmu-ilmu sosial bertujuan untuk mengembangkan pada diri siswa pengetahuan yang dapat dimanfaatkan bagi kepentingan diri dan masyarakatnya. Pembelajaran IPS tersebut untuk bekal di kehidupan lingkungan bermasyarakat. Pembelajaran IPS tersebut bermanfaat bagi siswa agar memperoleh pemahaman yang lebih luas dan mendalam tentang permasalahan sosial.

Chapin (2009, p.6) menjelaskan bahwa tujuan IPS sebagai berikut: "1) to acquire knowladge from the social sciences, history, and humanities; 2) to develop skills to think and to process information; 3) to develop appropiate democratic values and beliefs; 4) to have opportunities for citizenship/ social participation". Artinya IPS bertujuan untuk 1) memperoleh pengetahuan dari ilmu-ilmu sosial, sejarah, dan humaniora; 2) untuk mengembangkan keterampilan berpikir dan memproses informasi; 3) untuk mengembangkan telah sesuai nilai-nilai dan keyakinan demokratis; 4) memiliki peluang untuk partisipasi sosial.

Trianto (2010, p.176) mengungkapkan bahwa tujuan utama IPS adalah untuk mengembangkan potensi siswa agar peka terhadap masalah sosial yang terjadi dalam masyarakat, memiliki sikap mental positif terhadap perbaikan segala ketimpangan yang terjadi, dan terampil mengatasi setiap masalah yang terjadi sehari-hari baik yang menimpa dirinya sendiri maupun masyarakat. Tujuan mata pelajaran IPS untuk mengembangkan siswa agar peka terhadap masalah sosial yang terjadi di masyarakat, memiliki sikap mental positif terhadap perbaikan segala ketimpangan yang terjadi, dan terampil mengatasi setiap masalah yang terjadi sehari-hari baik yang menimpa dirinya sendiri maupun yang menimpa masyarakat

Langkah-langkah kreatif dan inovatif dalam pembelajaran adalah melalui penerapan atau pemilihan metode pembelajaran yang tepat. Hal ini dilakukan oleh guru dengan harapan dapat meningkatkan hasil belajar afektif siswa. Proses pembelajaran dituntut melibatkan peran aktif guru dengan siswa yang membiasakan siswa untuk terlibat langsung dalam proses pembelajaran. Cara lain melibatkan peran aktif siswa dengan memberikan kesempatan seluas-luasnya bagi siswa untuk berkembang sesuai dengan kemampuannya sendiri. Hal ini dilakukan agar siswa tertarik dalam proses pembelajaran tersebut.

Penerapan atau pemilihan metode pembelajaran yang tepat yang dilakukan guru diharapkan dapat meningkatkan hasil belajar siswa. Djamarah (2006, p.158) menjabarkan bahwa penggunaan metode mengajar yang bervariasi dapat menggairahkan belajar anak didik, pada suatu kondisi tertentu seorang anak akan merasa bosan dengan metode ceramah maka guru perlu mengalihkan suasana dengan menggunakan metode lain seperti: metode tanya jawab, diskusi atau metode penugasan sehingga kebosanan dapat terobati dan suasana kegiatan pengajaran jauh dari kelesuan. Sama halnya dengan pembelajaran IPS, mengingat cakupan materi IPS yang cukup luas seorang guru IPS harus mampu menentukan metode yang tepat dan bervariasi supaya tujuan pembelajaran dapat terpenuhi serta pembelajaran tidak terkesan membosankan.

Pembelajaran yang terjadi selama ini masih didominasi guru. Solihatin \& Raharjo (2012, p.3) mengungkapkan bahwa situasi pembelajaran di lapangan menunjukkan bahwa: (a) model pembelajaran cenderung ceramah, (b) siswa hanya dijadikan objek pembelajaran, (c) pembelajaran yang berlangsung cenderung didominasi guru, dan (d) dalam pembelajaran pola interaksinya searah yaitu dari guru ke siswa. Ketidakaktifan siswa selama proses pembelajaran merupakan salah satu faktor yang dapat mengakibatkan siswa sulit memahami konsep suatu materi pelajaran. Pembelajaran seperti ini tidak dapat melatih dan mengembangkan cara berpikir siswa. Hal tersebut menyebabkan proses pembelajaran kurang kondusif karena siswa cenderung tidak memperhatikan materi yang diajarkan oleh guru, sehingga siswa tidak dapat memecahkan masalah dan malas mengikuti pembelajaran.

Pembelajaran yang monoton menimbulkan ketidaktertarikan siswa terhadap pelajaran IPS. Guru IPS dalam proses pembelajaran masih menggunakan metode ceramah. Metode ceramah di depan kelas membuat siswa merasa tidak tertarik dalam proses pembelajaran. Penggunaan dominasi ceramah tersebut menyebabkan perhatian, minat, dan siswa cenderung pasif saat pembelajaran IPS seperti: berpendapat, bertanya, dan menjawab pertanyaan dari guru jika ditunjuk. Kurangnya pengetahuan akan metode pembelajaran yang variatif menjadi 
kendala dalam melaksanakan pembelajaran yang inovatif. Siswa kurang aktif dalam memberikan pendapat atau tanggapan dalam proses pembelajaran.

Peranan guru sangat penting dalam melakukan usaha-usaha untuk menumbuhkan dan memberikan motivasi agar siswa melakukan aktivitas belajar dengan baik. Guru dituntut merancang pembelajaran yang menarik dan memberikan pengalaman kepada siswa secara langsung dalam pembelajaran. Pembelajaran IPS harus memudahkan siswa untuk mampu membuat pilihan secara rasional dan membuat siswa dapat menggunakan konsep-konsep IPS untuk menganalisis persoalan-persoalan sosial yang ada. Pemahaman konsep-konsep yang baik dan pemikiran kritis semestinya akan mempermudah mereka dalam mencapai Kriteria Ketuntasan Minimal (KKM) yang telah ditetapkan oleh sekolah.

Keberhasilan dalam pembelajaran IPS sangat bergantung pada kemampuan guru dalam mendesain dan menentukan arah tujuan pembelajaran. Keberhasilan belajar seseorang tidak terlepas dari pengaruh metode pembelajaran yang digunakan. Pengaruh tersebut berguna untuk menciptakan kondisi belajar yang kondusif, menyenangkan, dan terjadi interaksi yang baik dengan siswa. Melalui pengaruh metode pembelajaran tersebut diharapkan hasil belajar siswa dapat ditingkatkan. Salah satu metode yang dipakai dalam pembelajaran IPS di sekolah adalah metode pembelajaran Active Debate.

Metode ini merupakan metode pembelajaran yang berpusat pada siswa. Metode Active Debate mendorong siswa untuk menyalurkan ide, gagasan, dan pendapatnya dalam pembelajaran, hal ini merupakan strategi yang secara aktif melibatkan setiap siswa di dalam kelas. Melalui penerapan metode pembelajaran ini diharapkan membantu meningkatkan hasil belajar afektif siswa. Hasil belajar siswa menjadi salah satu indikator keberhasilan dalam proses pembelajaran. Hasil belajar yang tinggi merupakan gambaran kemampuan siswa dalam menguasai materi yang telah disampaikan oleh guru. Hasil belajar juga merupakan indikator keberhasilan seorang guru dalam melaksanakan pembelajaran. Untuk meningkatkan hasil belajar IPS maka diperlukan suatu metode pembelajaran yang mengutamakan keterlibatan siswa secara langsung.
Seorang siswa dapat dikatakan telah mencapai hasil belajar jika dirinya telah terjadi perubahan tertentu melalui kegiatan belajar. Slameto (2010, p.54) menjelaskan faktor-faktor yang mempengaruhi hasil belajar banyak jenisnya, tetapi dapat di golongkan menjadi dua golongan saja, yaitu faktor intern dan faktor ekstern. Faktor-faktor tersebut sangat mempengaruhi hasil belajar yang siswa alami di sekolah. Penyebab utama kesulitan belajar (learning difficulty) adalah faktor internal yaitu diantaranya minat, bakat, motivasi, tingkat intelegensi, sedangkan penyebab utama masalah belajar (learning problems) adalah faktor eksternal antara lain berupa penerapan metode pembelajaran yang kurang tepat, serta pengelolaan kegiatan belajar yang tidak membangkitkan motivasi belajar.

Hasil nilai rata-rata ulangan harian IPS siswa di SMP Negeri 1 Jatisrono pada tahun ajaran 2015/2016 masih di bawah Kriteria Ketuntasan Minimal (KKM). Dapat dilihat dari tabel di bawah ini.

Tabel 1. Nilai Rata-rata Ulangan Harian

\begin{tabular}{|c|c|c|c|c|}
\hline \multirow{2}{*}{ Kelas } & \multirow{2}{*}{ KKM } & \multicolumn{3}{|c|}{ Nilai Rata-rata Ulangan } \\
& & $\mathbf{1}$ & $\mathbf{2}$ & $\mathbf{3}$ \\
\cline { 3 - 5 } & & 67,90 & 68,50 & 69,80 \\
\hline VII B & 70 & 68,25 & 68,00 & 69,60 \\
\hline VII C & 70 & \multicolumn{3}{|c}{} \\
\hline
\end{tabular}

Dari data di atas dapat dilihat bahwa rata-rata nilai ulangan harian masih di bawah KKM. Terdapat beberapa faktor yang menyebabkan pembelajaran belum mencapai KKM seperti, tingkat pemahaman siswa, saran pendukung pembelajaran, dan cara guru menyampaikan materi pembelajaran. Penelitian ini menitikberatkan terhadap pengaruh metode Active Debate terhadap hasil belajar afektif siswa. Metode Active Debate digunakan dalam penelitian ini karena memiliki kelebihan dalam meningkatkan hasil belajar afektif siswa. Melalui penerapan metode Active Debate ini siswa dapat mencari berbagai macam cara dalam menyelesaikan masalah dalam proses pembelajaran yang dilakukan di sekolah.

\section{Metode Active Debate}

Metode Active Debate merupakan metode yang sangat tepat dan strategis untuk mengembangkan kemampuan berfikir dan mengasah ketrampilan berbicara siswa. Metode ini sangat penting untuk meningkatkan 
kemampuan akademik siswa. Hall (2011) menyatakan bahwa menyatakan bahwa "Debate is a popular teaching tool in schools and at its tertiary levels where it is used in various disciplines. Debate promotes critical thinking and offers many advantages all in one go" Debat adalah alat pengajaran yang populer di sekolah dan di tingkat tersier dimana ia digunakan dalam berbagai disiplin ilmu. Perdebatan mempromosikan pemikiran kritis dan menawarkan banyak keuntungan sekaligus.

Mellgren \& Iven (2016, p.4) menjelaskan bahwa "the debate format has the potential to combine teaching course content, developing critical thinking skills and foster deep learning among the students by getting them actively involved and interested in the task". Artinya format debat memiliki potensi untuk menggabungkan isi kursus mengajar, berkembang kritis kemampuan berpikir dan mendorong pembelajaran mendalam di kalangan siswa dengan melibatkan mereka secara aktif tertarik pada pembelajaran.

Sohimin (2016, p.25) menjelaskan metode Active Debate merupakan kegiatan adu pendapat atau arguentasi antara dua pihak atau lebih, baik secara perorangan maupun kelompok, dalam mendiskusikan dan memutuskan masalah dan perbedaan. Shamsudin (2017, p.146) menjelaskan "debate is an activity which involves discussion on a matter with people whose opinions are different and/or contradictory". Debat adalah kegiatan yang melibatkan diskusi tentang masalah dengan orang-orang yang pendapatnya berbeda dan / atau kontradiktif.

Ismail (2007, p.81) menjelaskan bahwasannya tujuan dari metode debat aktif ini adalah untuk melatih siswaagar mencari argumentasi yang kuat dalam memecahkan suatu masalah yang kontroversial serta memiliki sikap demokratis dan saling menghormati terhadap perbedaan pendapat. Sanjaya (2009, p.154) menjelaskan bahwa metode debat merupakan metode pengajaran yang menghadapkan siswa pada suatu permasalahan. Adanya permasalahan tersebut diharapkan siswa akan dapat memecahkan suatu permasalahan, menjawab pertanyaan, menambah dan memahami pengetahuan siswa serta untuk membuat suatu keputusan
Hasil Belajar

Hasil belajar digunakan oleh guru untuk dijadikan ukuran atau kriteria dalam mencapai suatu tujuan pendidikan Hasil belajar merupakan hal yang tidak dapat dipisahkan dari kegiatan belajar karena kegiatan belajar merupakan proses. Duffy \& McDonald (2010, p.28) menjelaskan "Learning is a complex activity that can be explained differently depending on one's perspective on how and why people do what they do". Belajar merupakan aktivitas yang kompleks dan dapat dijelaskan dengan makna yang berbeda tergantung pada perspektif mengapa dan bagaimana orang melakukannya.

Sudjana (2011, p.22) menjelaskan bahwa hasil belajar merupakan kemampuankemampuan yang dimiliki siswa setelah ia menerima pengalaman belajarnya. Hasil belajar atau prestasi belajar biasa juga kita artikan sebagai suatu pencapaian keberhasilan, dalam hal ini yang dimaksud adalah keberhasilan siswa selama mengikuti proses pembelajaran di sekolah. Chiappetta \& Koballa (2010, p.37) menyatakan bahwa "specifies the understandings that students should construct as a result of instructions". Artinya perlu adanya penanaman pemahaman pada siswa harus menunjukkan perubahan perilaku dan sebaginya sebagai hasil pengajaran.

Suharto \& Zamroni (2016, p.83) menyatakan hasil belajar siswa yang tercermin dalam angka atau nilai mata pelajaran mempunyai beberapa fungsi nilai. Salah satu fungsi nilai hasil belajar sebagai data, informasi, dan petunjuk mengenai tingkat pengetahuan, pemahaman, dan penguasaan materi serta ketrampilan siswa. Hal ini dipengaruhi beberapa faktor yang mempengaruhi hasil belajar siswa agar tercapai tujuan pembelajaran yang diinginkan. Purwanto (2006, p.102) menyampaikan bahwa hasil belajar dipengaruhi oleh beberapa faktor, yaitu: Pertama, faktor dari luar individu yang terdiri dari lingkungan (alam dan sosial) dan instrumental (kurikulum/bahan pelajaran, guru/pengajar, sarana dan fasilitas, serta administrasi/manajemen); Kedua, faktor dari dalam individu yang terdiri dari fisiologi (kondisi fisik dan kondisi panca indera) dan psikologi (bakat, minat, kecerdasan, motivasi dan kemampuan kognitif). 
Pembelajaran afektif mencirikan area emosional pembelajaran yang tercermin dari kepercayaan, nilai, minat, dan perilaku peserta didik (Krathwohl et al., 1964; Smith \& Ragan, 1999; Gronlund \& Brookhart, 2009). Ramalingam (2014, p.29) menyatakan "the affective domain is not best handled with just text on a screen, class meetings or an initial class meeting to support an online course might be used for affective development". Domain afektif tidak terbaik ditangani hanya dengan teks, pertemuan kelas atau pertemuan kelas awal untuk mendukung kursus online dapat digunakan untuk pengembangan afektif.

Ciri-ciri hasil belajar afektif akan tampak pada siswa dalam berbagai tingkah laku. Hasil belajar ranah afektif ini oleh Krathwohl (Sudijono, 2013, p.54) ditaksonomi menjadi lebih rinci lagi ke dalam lima jenjang, yaitu: 1) menerima (receiving), 2) menanggapi (responding), 3) menilai (valuing), 4) mengorganisasikan (organization), dan 5) karakterisasi dengan suatu nilai atau komplek nilai (characterization by a value or value complex).

Penelitian ini hasil belajar dapat dilihat dari ranah afektif. Indikator hasil belajar afektif berupa sikap spiritual dan sikap sosial. Pengembangan indikator sikap spiritual dan sikap sosial siswa dapat dilakukan oleh guru dan pihak sekolah. Indikator yang dipaparkan di atas memberikan gambaran standar yang dapat diterapkan di sekolah. Pembentukan nilai spiritual dan nilai sosial siswa dapat dilakukan melalui berbagai kegiatan di sekolah. Salah satu kegiatan yang digunakan adalah proses pembelajaran khususnya pembelajaran IPS. Karakter siswa dapat diamati dan diukur dengan menggunakan beberapa indikator. Indikator telah diuraikan sebelumnya dapat dijadikan ukuran siswa selama di sekolah ataupun di kelas dengan melakukan penyesuaian. Pengembangan indikator tersebut dapat dilakukan untuk mewujudkan siswa yang berkarakter. Pembentukan karakter siswa tersebut dapat dilakukan dengan mengintegrasikannya dalam setiap pembelajaran di kelas.

\section{Metode Penelitian}

Penelitian ini merupakan jenis penelitian eksperimen semu (quasi experimental). Sukmadinata (2013, p.59) mengungkapkan prosedur dan syarat eksperimen terutama berkenaan dengan pengontrolan variabel, semua variabel dikontrol atau dicari yang sama. Secara umum tujuan dari penelitian ini adalah untuk mengetahui pengaruh pembelajaran dengan metode Active Debate terhadap hasil belajar afektif siswa. Desain penelitian yang digunakan dalam penelitian ini adalah menggunakan pretest posttest non-equivalent design.

Penelitian ini dilaksanakan di SMP Negeri 1 Jatisrono, Kabupaten Wonogiri. Waktu penelitian dilaksanakan pada waktu mata pelajaran IPS kelas VII SMP Negeri 1 Jatisrono semester ganjil tahun pelajaran 2017/2018 pada bulan Juli-Agustus 2017.

Populasi dalam penelitian ini adalah seluruh siswa kelas VII SMP Negeri 1 Jatisrono yang terdaftar pada tahun ajaran 2017/2018 yang terdiri dari 10 kelas dengan jumlah siswa 307 orang. Sampel dalam penelitian ini dipilih dengan menggunakan teknik Random Sampling, yaitu dilakukan secara acak tanpa memperhatikan strata yang ada. Pengambilan sampel dengan teknik Random Sampling dilakukan dengan mengambil secara acak 2 kelas dari 10 kelas dengan melakukan undian pada kelas VII tersebut. Hasil undian diperoleh kelas VII D sebagai kelas eksperimen yang akan diajarkan dengan metode Active Debate, kelas VII C sebagai kelas kontrol yang akan diajarkan dengan metode ceramah sesuai yang diterapkan pada sekolah tersebut.

Teknik pengumpulan data merupakan tahapan dalam mengumpulkan data. Pada penelitian ini, data diperoleh langsung oleh peneliti sehingga data tersebut merupakan data primer. Tahapan pengumpulan data dilakukan sebagai berikut: 1) menyusun perangkat penelitian yang terdiri dari silabus, RPP, angket, dan rubrik penskoran sesuai variabel yang akan diteliti; 2) menentukan validitas isi; 3) melakukan uji coba instrumen. Instrumen penelitian akan di uji coba sebelum digunakan untuk mengambil data guna untuk mengetahui validitas konstruk dan reliabilitas, 4) memberikan angket hasil belajar afektif siswa sebelum perlakuan, 5) memberikan pretest angket hasil belajar afektif siswa berupa angket awal sebelum perlakuan, 6) memberikan posttest angket hasil belajar afektif siswa berupa angket akhir setelah perlakuan.

Instrumen penelitian yang digunakan dalam penelitian ini adalah instrumen non tes. Instrumen non tes berupa angket untuk hasil belajar afektif siswa (sikap spiritual dan sikap sosial). Data hasil belajar afektif dilihat dari 
aspek sikap siswa dinilai dengan penilaian diri dalam bentuk checklist yang berupa pernyataan positif, siswa hanya memilih salah satu jawaban dari 4 kategori yang disediakan. Skala penilaian diri yang digunakan dalam penelitian ini adalah skala Likert, yaitu dengan 3 nilai tertinggi dan 1 nilai terendah.

Penelitian ini, validitas yang digunakan yaitu validitas isi dan validitas konstruk. Validitas isi harus menjawab pertanyaan sejauh mana instrumen yang digunakan itu mencakup keseluruhan situasi yang ingin diukur. Cara menentukan validitas isi, yaitu validitas isi disahkan oleh dosen ahli dan validitas isi dilakukan secara kuantitatif dengan melihat masukan sebagai perbaikan butir instrumen. Dosen ahli melakukan penilaian terhadap intrumen yang digunakan dalam penelitan. Menentukan validitas isi adalah merupakan penilaian dan masukan dari dosen sebagai validator instrumen yang diuji cobakan.

Validitas konstruk dilakukan dengan cara menyusun instrumen berdasarkan kajian teori kemudian di konsultasikan dengan dosen. Hasil revisi dari dosen pembimbing kemudian disusun dan diuji cobakan. Hasil uji coba instrumen akan di analisis dan daya beda butir instrumen akan dianalisis dengan mengkorelasikan skor item dan skor total dengan asumsi bahwa skor item dan skor total signifikan. Teknik analisis data yang digunakan untuk mengukur hasil belajar afektif siswa adalah analisis statistik deskriptif, uji prasyarat, dan uji analisis data.

\section{Hasil Penelitian dan Pembahasan}

\section{Deskripsi Hasil Belajar Afektif Siswa (Sikap Spiritual dan Sikap Sosial) Sebelum dan Setelah Perlakuan}

Data hasil belajar afektif siswa (sikap spiritual dan sikap sosial) yang akan dideskripsikan terdiri atas data pretest dan posttest. Pretest merupakan angket yang diberikan pada ketiga kelas sebelum diberikan perlakuan. Tujuan angket ini yaitu untuk mengetahui karakter sikap spiritual dan sikap sosial siswa sebelum perlakuan. Posttest merupakan angket yang diberikan setelah dilaksanakan perlakuan. Angket ini bertujuan untuk mengetahui karakter sikap spiritual dan sikap sosial siswa setelah diberikan perlakuan. Hasil angket karakter sikap spiritual dan sikap sosial siswa disajikan pada Tabel 2.
Tabel 2. Deskripsi Data Hasil Belajar Afektif (Sikap Spiritual dan Sikap Sosial) Siswa Pretest dan Posttest Eksperimen dan Kontrol

\begin{tabular}{|c|c|c|c|c|c|}
\hline \multirow{2}{*}{ No. } & \multirow{2}{*}{ Deskripsi } & \multicolumn{2}{|c|}{ Eksperimen } & \multicolumn{2}{|c|}{ Kontrol } \\
\cline { 3 - 6 } 1 & Pretest & Posttest & Pretest & Posttest \\
\hline Banyak Siswa & 30 & 30 & 30 & 30 \\
\hline 2 & $\begin{array}{c}\text { Mean (Rata- } \\
\text { rata) }\end{array}$ & 81,13 & 96,13 & 80,00 & 85,00 \\
\hline 3 & $\begin{array}{c}\text { Standar } \\
\text { Deviasi }\end{array}$ & 6,73 & 6,73 & 4,70 & 4,70 \\
\hline 5 & $\begin{array}{c}\text { Nilai } \\
\text { Minimum }\end{array}$ & 63,00 & 78,00 & 63,00 & 75,00 \\
\hline $\begin{array}{c}\text { Nilai } \\
\text { Maksimum }\end{array}$ & 93,00 & 108,00 & 93,00 & 93,00 \\
\hline
\end{tabular}

Tabel deskripsi ini memuat hasil data statistik deskriptif seperti mean (rata-rata), standar deviasi, nilai minimum, dan nilai maksimum sebelum dan setelah perlakuan. Pada data terlihat bahwa mean (rata-rata) kelas eksperimen sebelum perlakuan adalah 81,13 dan setelah perlakuan sebesar 96,13 dan mean (rata-rata) kelas kontrol sebelum perlakuan adalah 80,00 dan setelah perlakuan sebesar 85,00 . Standar deviasi kelas eksperimen sebelum dan setelah perlakuan sebesar 6,73, standar deviasi kelas kontrol sebelum dan setelah perlakuan sebesar 4,70 .

Nilai minimum kelas eksperimen sebelum perlakuan adalah 63,00 dan setelah perlakuan sebesar 78,00 , nilai minimum kelas kontrol sebelum perlakuan adalah 63,00 dan setelah perlakuan sebesar 75,00. Nilai maksimum kelas eksperimen sebelum perlakuan adalah 93,00 dan setelah perlakuan adalah 108,00 dan nilai maksimum kelas kontrol sebelum perlakuan dan setelah perlakuan adalah 93,00. 


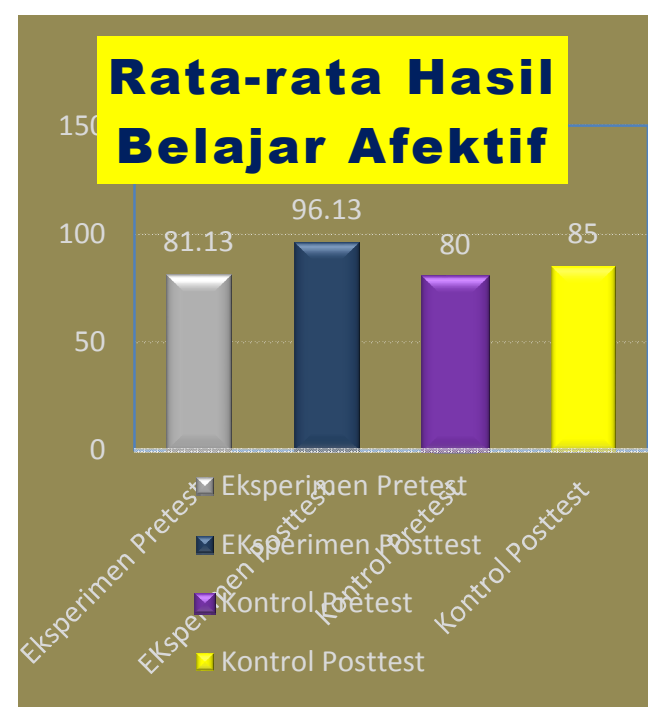

Gambar 1. Grafik Perbandingan Rata-Rata Nilai Pretest dan Posttest Hasil Belajar Afektif Kelas Eksperimen dan Kontrol

\section{Data Hasil Pretest Hasil Belajar Afektif (Sikap Spiritual dan Sosial) \\ Kelas Eksperimen \\ Frekuensi dan persentase dari hasil kategorisasi awal hasil belajar afektif siswa pada kelas eksperimen dapat dilihat pada Tabel 3.}

Tabel 3. Kategorisasi Hasil Belajar Afektif Siswa Sebelum Perlakuan Kelas Eksperimen

\begin{tabular}{|l|l|l|l|}
\hline $\begin{array}{l}\text { Interval } \\
\text { Skor }\end{array}$ & Kategorisasi & $\begin{array}{l}\text { Freku- } \\
\text { ensi }\end{array}$ & $\begin{array}{l}\text { Presenta } \\
\text { se }\end{array}$ \\
\hline $\mathrm{X} \geq 88$ & Sangat Tinggi & 5 & $17 \%$ \\
\hline $88>\mathrm{X} \geq 81$ & Tinggi & 10 & $33 \%$ \\
\hline $81>\mathrm{X} \geq 74$ & Rendah & 11 & $37 \%$ \\
\hline $\mathrm{X}<74$ & Sangat Rendah & 4 & $13 \%$ \\
\hline
\end{tabular}

Tabel 3 dapat dilihat bahwa kategori hasil belajar afektif siswa sebelum perlakuan (pretest) pada kelas eksperimen dengan menggunakan metode Active Debate sebanyak 5 siswa dalam kategori sangat tinggi dengan persentase $17 \%, 10$ siswa dalam kategori tinggi dengan persentase $33 \%, \quad 11$ siswa dalam kategori rendah dengan persentase $37 \%, 4$ siswa dalam kategori sangat rendah dengan persentase $13 \%$. Hal ini menunjukkan bahwa kategori rendah memiliki frekuensi terbanyak yaitu
11 siswa dengan persentase $37 \%$. Hal ini berarti bahwa hasil belajar afektif siswa tinggi dengan interval skor $81>X \geq 74$.

\section{Kelas Kontrol}

Frekuensi dan persentase dari hasil kategorisasi awal hasil belajar afektif siswa pada kelas kontrol dapat dilihat pada Tabel 4.

Tabel 4. Kategorisasi Hasil Belajar Afektif Siswa Sebelum Perlakuan Kelas Kontrol

\begin{tabular}{|l|l|c|c|}
\hline $\begin{array}{c}\text { Interval } \\
\text { Skor }\end{array}$ & \multicolumn{1}{|c|}{ Kategorisasi } & $\begin{array}{c}\text { Freku } \\
\text { ensi }\end{array}$ & $\begin{array}{c}\text { Prese } \\
\text { ntase }\end{array}$ \\
\hline $\mathrm{X} \geq 89$ & Sangat Tinggi & 6 & $20 \%$ \\
\hline $89>\mathrm{X} \geq 83$ & Tinggi & 13 & $43 \%$ \\
\hline $83>\mathrm{X} \geq 77$ & Rendah & 7 & $23 \%$ \\
\hline $\mathrm{X}<77$ & Sangat Rendah & 4 & $13 \%$ \\
\hline
\end{tabular}

Tabel 4 dapat dilihat bahwa kategori hasil belajar afektif siswa sebelum perlakuan (pretest) pada kelas kontrol dengan menggunakan metode ceramah sebanyak 6 siswa dalam kategori sangat tinggi dengan persentase $20 \%, 13$ siswa dalam kategori tinggi dengan persentase 43\%, 7 siswa dalam kategori rendah dengan persentase $23 \%, 4$ siswa dalam kategori sangat rendah dengan persentase 13\%. Hal ini menunjukkan bahwa kategori tinggi memiliki frekuensi terbanyak yaitu 13 siswa dengan persentase $343 \%$. Hal ini berarti bahwa hasil belajar afektif siswa tinggi dengan interval skor $89>X \geq 83$.

\section{Data Hasil Posttest Hasil Belajar Afektif (Sikap Spiritual dan Sosial)}

\section{Kelas Eksperimen}

Frekuensi dan persentase dari kategorisasi hasil belajar afektif siswa setelah perlakuan pada kelas eksperimen dapat dilihat pada Tabel 5.

Tabel 5. Perlakuan Kelas Eksperimen

\begin{tabular}{|l|l|l|l|}
\hline Interval Skor & Kategorisasi & $\begin{array}{l}\text { Frek } \\
\text { uensi }\end{array}$ & $\begin{array}{l}\text { Presen } \\
\text { tase }\end{array}$ \\
\hline$X \geq 103$ & Sangat Tinggi & 5 & $17 \%$ \\
\hline $103>X \geq 96$ & Tinggi & 10 & $33 \%$ \\
\hline $96>X \geq 89$ & Rendah & 11 & $37 \%$ \\
\hline$X<89$ & Sangat Rendah & 4 & $13 \%$ \\
\hline
\end{tabular}

Tabel 5 dapat dilihat bahwa kategori hasil belajar afektif siswa setelah perlakuan (posttest) pada kelas kontrol dengan menggunakan metode Active Debate sebanyak 5 siswa dalam kategori sangat tinggi dengan persentase $17 \%, 10$ siswa 
dalam kategori tinggi dengan persentase $33 \%, \quad 11$ siswa dalam kategori rendah dengan persentase $37 \%, 4$ siswa dalam kategori sangat rendah dengan persentase 13\%. Hal ini menunjukkan bahwa kategori rendah memiliki frekuensi terbanyak yaitu 11 siswa dengan persentase $37 \%$. Hal ini berarti bahwa hasil belajar afektif siswa tinggi dengan interval skor $96>X \geq 89$.

\section{Kelas Kontrol}

Frekuensi dan persentase dari kategorisasi hasil belajar afektif siswa setelah perlakuan pada kelas kontrol dapat dilihat pada Tabel 6 .

\section{Tabel 6. Kategorisasi Hasil Belajar Afektif Siswa Setelah Perlakuan Kelas Kontrol}

\begin{tabular}{|l|l|c|c|}
\hline $\begin{array}{c}\text { Interval } \\
\text { Skor }\end{array}$ & \multicolumn{1}{|c|}{ Kategorisasi } & $\begin{array}{c}\text { Freku } \\
\text { ensi }\end{array}$ & $\begin{array}{c}\text { Present } \\
\text { ase }\end{array}$ \\
\hline $\mathrm{X} \geq 99$ & Sangat Tinggi & 6 & $20 \%$ \\
\hline $99>\mathrm{X} \geq 93$ & Tinggi & 13 & $43 \%$ \\
\hline $93>\mathrm{X} \geq 87$ & Rendah & 7 & $23 \%$ \\
\hline $\mathrm{X}<87$ & Sangat Rendah & 4 & $13 \%$ \\
\hline
\end{tabular}

Tabel 6 dapat dilihat bahwa kategori hasil belajar afektif siswa setelah perlakuan (posttest) pada kelas eksperimen dengan menggunakan metode ceramah sebanyak 6 siswa dalam kategori sangat tinggi dengan persentase $20 \%, 13$ siswa dalam kategori tinggi dengan persentase $43 \%, 7$ siswa dalam kategori rendah dengan persentase 23\%, 4 siswa dalam kategori sangat rendah dengan persentase $13 \%$. Kategori tinggi memiliki frekuensi terbanyak yaitu 130 siswa dengan persentase $43 \%$. Hal ini berarti bahwa hasil belajar afektif siswa tinggi dengan interval skor $99>X \geq 93$.

\section{Analisis Data}

\section{Uji Normalitas}

Uji normalitas dilakukan untuk mengetahui apakah data- data berdistribusi normal atau tidak normal pada data kelas eksperimen dan kelas kontrol. Penelitian ini menggunakan metode kolmogrov-smirnov untuk pengujian normalitas dengan bantuan software SPSS 22.0 for windows. Kriteria pengujian berasal dari populasi data yang terdistribusi normal jika nilai signifikansinya lebih besar dari 0,05. Berdasarkan analisis yang telah dilakukan, hasil uji normalitas disajikan pada Tabel 7 menunjukkan data uji normalitas univariat diperoleh nilai signifikansi lebih dari 0,05. Hal ini menunjukkan bahwa data berdistribusi normal. Oleh karena itu, data dapat digunakan.

\section{Tabel 7. Hasil Uji Normalitas Sebelum dan} Setelah Perlakuan

\begin{tabular}{|l|l|l|}
\hline \multirow{2}{*}{ Variabel } & Kolmogorov Smirnov & \multirow{2}{*}{ Keterangan } \\
\cline { 2 - 3 } & Hasil Belajar Afektif & \\
\hline Pretest eksperimen & $0,200^{*}$ & $\begin{array}{l}\text { Distribusi } \\
\text { Normal }\end{array}$ \\
\hline Posttest eksperimen & $0,200^{*}$ & $\begin{array}{l}\text { Distribusi } \\
\text { Normal }\end{array}$ \\
\hline Pretest kontrol & 0,180 & $\begin{array}{l}\text { Distribusi } \\
\text { Normal }\end{array}$ \\
\hline Posttest kontrol & 0,143 & $\begin{array}{l}\text { Distribusi } \\
\text { Normal }\end{array}$ \\
\hline
\end{tabular}

\section{Uji Homogenitas}

Uji homogenitas dimaksudkan untuk mengetahui data yang dianalisis homogen atau tidak. Kriteria pengujian berasal dari populasi data yang homogen jika nilai signifikansinya lebih besar dari 0,05. Pengujian homogenitas untuk uji multivariat menggunakan uji Levene Statistic jika tidak ada perbedaan atau kedua varians-kovarians sama. Berikut hasil analisis uji homogenitas yang dilakuan dengan bantuan software SPSS 22.0 for windows dapat dilihat pada Tabel 8.

\section{Tabel 8. Hasil Uji Homogenitas Data Sebelum dan Setelah Perlakuan}

\begin{tabular}{|c|c|c|c|c|}
\hline Variabel & Levene Statistic & df $\mathbf{1}$ & df 2 & Sig \\
\hline Pretest & 3,387 & 1 & 58 & 0,71 \\
\hline Posttest & 3,387 & 1 & 58 & 0,71 \\
\hline
\end{tabular}

Tabel di atas dapat diketahui bahwa besarnya nilai Levene Statistic sebelum dan setelah perlakuan adalah 3,387, sedangkan tingkat signifikansinya adalah 0,71 yang berarti lebih besar dari 0,05 . Hal ini menunjukkan hasil perhitungan menggunakan software SPSS 22.0 for windows menunjukkan matriks varianskovarians pada variabel dependen adalah homogen. 


\section{Uji Hipotesis}

Hipotesis dalam penelitian ini terdapat pengaruh metode Active Debate terhadap hasil belajar afektif siswa dalam pembelajaran IPS di SMP Negeri 1 Jatisrono. Uji hipotesis dilakukan dengan analisis regresi untuk melihat pengaruh metode Active Debate terhadap terhadap hasil belajar afektif siswa. Kaidah keputusan yang digunakan apabila nilai sig. $\leq 0,05$, maka $\mathrm{H}_{1}$ diterima.

\section{Tabel 9. Hasil Uji Hipotesis Metode dan Hasil Belajar Afektif Siswa}

\begin{tabular}{|c|c|c|c|c|c|}
\hline \multicolumn{6}{|c|}{ Coefficients ${ }^{\mathrm{a}}$} \\
\hline \multirow[b]{2}{*}{ Model } & \multicolumn{2}{|c|}{$\begin{array}{l}\text { Unstandardized } \\
\text { Coefficients }\end{array}$} & $\left|\begin{array}{c}\text { Standardiz } \\
\text { ed } \\
\text { Coefficient } \\
s\end{array}\right|$ & \multirow[b]{2}{*}{$t$} & \multirow[b]{2}{*}{ Sig. } \\
\hline & B & Std. Error & Beta & & \\
\hline (Constant) & 107.267 & 2.370 & & 45.251 & .000 \\
\hline metode & -11.133 & 1.499 & .698 & -7.426 & .000 \\
\hline
\end{tabular}

$$
\begin{aligned}
& \text { Persamaan Regresi } \\
& Y^{\wedge}=a+b X \\
& Y^{\wedge}=107,267-11,133 X
\end{aligned}
$$

Tabel 9 dapat dilihat bahwa nilai signifikansi sebesar 0,000 lebih kecil dari 0,05 . Hal ini berarti bahwa terdapat pengaruh metode Active Debate terhadap hasil belajar afektif siswa. Apabila sudah diketahui adanya pengaruh, tahap selanjutnya dilakukan uji lanjut, yaitu koefisien determinasi dengan untuk menentukan metode pembelajaran mana yang lebih berpengaruh secara signifikan.

Disimpulkan bahwa $\mathrm{H}_{1}$ diterima yang berarti ada perbedaan pengaruh antara metode Active Debate dan ceramah dalam pembelajaran IPS terhadap hasil belajar afektif siswa di SMP Negeri 1 Jatisrono. Metode pembelajaran mana yang lebih berpengaruh dalam pembelajaran IPS terhadap hasil belajar afektif siswa dapat diketahui dengan dilakukan uji koefisian determinasi. Hasil uji koefisian determinasi dapat dilihat pada Tabel 10.

\section{Tabel 10. Hasil Uji Koefisian} Determinasi

Model Summary

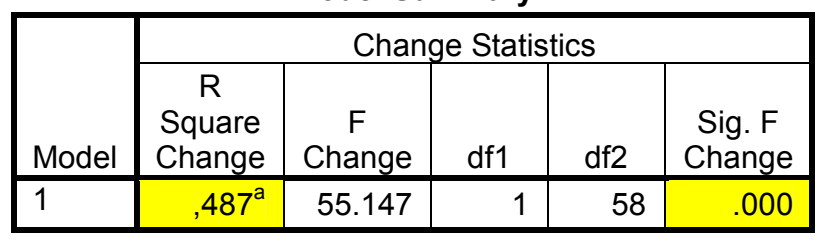

Dari tabel 30 dapat dilihat bahwa nilai koefisien determinasi sebesar 0,487. Berdasarkan hasil yang ditunjukkan tabel di atas dapat disimpulkan bahwa metode yang paling berpengaruh terhadap hasil belajar afektif siswa adalah metode Active Debate. Hal ini berarti sebesar $48,7 \%$ hasil belajar afektif dipengaruhi oleh metode Active Debate, sisanya $51,3 \%$ dipengaruhi faktor lain.

Terdapat pengaruh metode Active Debate dalam pembelajaran IPS terhadap hasil belajar afektif siswa

Hasil analisis data menunjukkan bahwa ada pengaruh metode Active Debate dalam pembelajaran IPS terhadap hasil belajar afektif siswa di SMP Negeri 1 Jatisrono. Hal ini diperoleh dengan melakukan analisis univariat dengan tujuan untuk mengetahui ada atau tidaknya pengaruh metode Active Debate dalam pembelajaran IPS terhadap hasil belajar afektif siswa. Kaidah keputusan yang digunakan adalah jika nilai sig. $\leq 0,05$, maka $\mathrm{H} 1$ diterima yang berarti bahwa ada pengaruh antara metode pembelajaran Active Debate dalam pembelajaran IPS terhadap hasil belajar afektif siswa. Setelah diketahui adanya perbedaan pengaruh signifikan maka dilanjutkan dengan uji koefisien determinasi.

Metode yang paling berpengaruh terhadap hasil belajar afektif siswa adalah metode Active Debate. Hal ini berarti sebesar $48,7 \%$ hasil belajar afektif dipengaruhi oleh metode Active Debate, sisanya 51,3\% dipengaruhi faktor lain. Metode Active Debate dalam pembelajaran IPS memiliki pengaruh terhadap hasil belajar afektif siswa berdasarkan pemaparan yang telah diuraikan. Penggunaan metode tersebut dapat dijadikan alternatif dalam 
pembelajaran IPS agar siswa lebih aktif dan menjadikan siswa lebih termotivasi dalam berpartisipasi saat pembelajaran berlangsung. Metode tersebut telah teruji memiliki pengaruh baik terhadap hasil belajar afektif siswa..

\section{Simpulan dan Saran}

Simpulan

Berdasarkan analisis data dan pembahasan, maka hasil penelitian dapat disimpulkan bahwa ada pengaruh metode Active Debate dalam pembelajaran IPS terhadap hasil belajar afektif siswa di SMP Negeri 1 Jatisrono. Peningkatan hasil belajar afektif siswa dengan angket yang diajar dengan metode Active Debate lebih tinggi dibandingkan peningkatan hasil belajar afektif siswa dengan angket yang diajar dengan metode ceramah. Hal ini dibuktikan dengan dilakukan uji lanjut post hoc bonferroni untuk mengetahui metode yang lebih berpengaruh terhadap hasil belajar afektif siswa. Hasil uji lanjut post hoc bonferroni yang menunjukkan metode Active Debate lebih berpengaruh daripada metode ceramah terhadap hasil belajar afektif siswa siswa di SMP Negeri 1 Jatisrono.

Saran

Berdasarkan simpulan dan implikasi yang telah diuraikan sebelumnya maka dapat dikemukakan saran-saran yaitu, hasil penelitian ini menunjukkan metode Active Debate lebih berpengaruh daripada metode ceramah, jika guru menggunakan metode Active Debate maka hasil belajar siswa akan mengalami peningkatan lebih tinggi dibandingkan apabila guru menggunakan metode ceramah. Sebaiknya guru menggunakan metode Active Debate untuk mendapatkan hasil belajar afektif siswa yang lebih tinggi.

Pembelajaran dengan menggunakan metode Active Debate memiliki pengaruh terhadap hasil belajar afektif siswa dibandingkan dengan metode ceramah, sehingga melalui pembelajaran yang menerapkan metode ini, siswa mampu memaknai pembelajaran yang dilakukan di sekolah dan siswa dapat mencari jalan keluar terhadap masalah-masalah sosial khususnya yang ada di sekitarnya.

\section{Daftar Pustaka}

Chapin, J.R. (2009). Elementary social studies. New York: Pearson Education.

Charif, M. (2010). The effects of problem based learning in chemistry education on middle school students' academic achievement and attitude. Tesis master, Lebanese American University, Beirut. Dari

http://laur.lau.edu.lb:7080/xmlui/bitstrea $\mathrm{m} /$ handle/10725/117/Thesis Mona Fayc al Charif.pdf?sequence $=1$

Djamarah, S.B. (2008). Psikologi belajar. Jakarta: Rineka Cipta.

Duffy, J. L., \& McDonald, J. B. (2010). Teaching and learning with technology. Boston: Pearson Education, Inc.

Gronlund, N. E., \& Brookhart, S. M. (2009). Writing instructional objectives (8th ed). Upper Saddle River, New Jersey: Pearson Education.

Hall, D. (2011). Debate: Innovative teaching to enhance critical thinking and communicative skills in healthcare professionals. The Internet Journal of Allied Sciences and Practice, 9(3), 1-8.

Hasan, H. (2013). IPS dalam kurikulum 2013. Makalah. Seminar Nasional. Yogyakarta: Pendidikan IPS FIS-UNY.

Ismail. (2007). Strategi pembelajaran agama Islam berbasis PAIKEM. Semarang: RaSAIL Media Group.

Krathwohl, D. R., Bloom, B. S., \& Masia, B. B. (1964). Taxonomy of educational objectives, the classification of educational goals. Handbook II: Affective domain. New York: David McKay Co, Inc.

Mohamad, A. (2015). Pendidikan Singapura terbaik sedunia, Indonesia cuma di atas Ghana. Diambil pada tanggal 23 Desember 2016, dari https://www.merdeka.com/dunia/pendi dikan-singapura-terbaik-seduniaindonesia-cuma-di-atas-ghana.html 
Purwanto, N. (2006). Psikologi pendidikan. Bandung: PT Remaja Rosdakarya.

Ramalingam, M. (2014). Assessment of learning domains to improve student's learning in higher education. Journal of Young Pharmacists, 6 (4), 27-33.

Sanjaya, W. (2009). Strategi pembelajaran berorientasi standar proses pendidikan. Jakarta: Prenada Media Group.

Shohimin, A. (2016). 68 model pembelajaran inovatif dalam kurikulum 2013. Yogyakarta: Ar-Ruzz Media.

Slameto. (2010). Belajar dan faktor-faktor yang mempengaruhinya. Jakarta: Rineka Cipta.

Smith, P. L., \& Ragan, T. J. (1999). Instructional design. New York: John Wiley \& Sons, Inc.

Solihatin, E., \& Raharjo. (2012). Cooperative learning: Analisis model pembelajaran IPS. Jakarta: PT.Bumi Aksara.

Solihatin, E., \& Raharjo. (2012). Cooperative learning: Analisis model pembelajaran IPS. Jakarta: PT.Bumi Aksara.

Sudijono, A. (2013). Pengantar evaluasi pendidikan. Jakarta: PT Rajagrafindo Persada.

Sudjana. (2000). Strategi pembelajaran. Bandung: Falah Production.

Suharto \& Zamroni. (2016). Peningkatan hasil dan aktivitas belajar IPS model problem-based learing berbantuan media SMP N 2 Kawunganten. Harmoni Sosial: Jurnal Pendidikan IPS, 3(1), 82-94.

Sukmadinata, N. S. (2013). Metode penelitian pendidikan. Bandung: PT Remaja Rosdakarya.

Trianto. (2010). Mendesain model pembelajaran inovatif-progresif. Jakarta: Kencana Prenada Media Group.
Zamroni. (2007). Pendidikan dan demokrasi dalam transisi (prakondisi menuju era globalisasi). Jakarta: PSAP

\section{Profil Singkat}

Happri Novriza Setya Dhewantoro, M. Pd.

Lahir di Wonogiri, 29 November 1993.

Tahun 2011, penulis diterima sebagai mahasiswa S1 prodi Pendidikan IPS, Universitas Negeri Yogyakarta, penulis berhasil menyelesaikan program sarjana pada tahun 2015. Tahun 2015, penulis melanjukan studi S2 dan diterima sebagai mahasiswa S2 prodi Pendidikan IPS. Tahun 2017, penulis berhasil menyelesaiakn program Magister di Universitas Negeri Yogyakarta.

Dr. Taat Wulandari, M. Pd.

Beliau merupakan tenaga professional dan staf pengajar di Jurusan IPS S1 dan S2 Universitas Negeri Yogyakarta. Bidang keahlian beliau pada Sejarah Amerika, Kepemimpinan Nasional, Penilaian Proses dan Hasil Belajar, Kepariwisataan, Nasionalisme dan Jati Diri Bangsa, Patologi dan Masalah Sosial, Sejarah Pemikiran. Lahir di Bantul, 11 Februari 1976. Menyelesaikan program doktor di Universitas Negeri Yogyakarta tahun 2013. 